\title{
Taxonomic notes on the genus Nervilia (Nervilieae: Epidendroideae: Orchidaceae) in Sri Lanka
}

\author{
Atthanagoda A.G. ${ }^{1}$, N. Aberathna ${ }^{2}$, C. Bandara ${ }^{3}$ \& P. Kumar ${ }^{4 *}$ \\ ${ }^{1}$ Institute of Biochemistry, Molecular Biology and Biotechnology, University of Colombo, Sri Lanka \\ ${ }^{2}$ Department of Veterinary and Pathobiology, Faculty of Veterinary Medicine and Animal Science, University of Peradeniya, Sri Lanka \\ ${ }^{3}$ Faculty of Applied Sciences, University of Sri Jayewardenepura, Gangodawila, Nugegoda, Sri Lanka \\ ${ }^{4}$ Kadoorie Farm and Botanical Garden, Lam Kam Road, Lam Tsuen, Tai Po, New Territories, Hong Kong S.A.R., P.R. China \\ *E-mail: pkumar@kfbg.org
}

\begin{abstract}
Three species of Nervilia Comm. ex Gaudich. are enumerated from Sri Lanka. A key to the identification of these three species is provided along with taxonomic details, descriptions and notes on flowering phenology, habitat and global distribution. The misidentification of the only species previously recorded in the country, N. juliana (Roxb.) Schltr., is resolved. Colour figures and line drawings are provided for all species.
\end{abstract}

Keywords: Misidentification, Nervilia concolor, Nervilia juliana, Nervilia plicata, Nervilia simplex.

\section{Introduction}

The genus Nervilia Comm. ex Gaudich. was established by the French naturalist Charles Gaudichaud-Beaupré (Gaudichaud, 1829) with the generic name being derived from the Latin word 'nervus', referring to the prominently veined leaves. The genus comprises around 78 species distributed from Africa to the Pacific (Govaerts et al., 2021).

During recent surveys in Sri Lanka, the current authors encountered a few species belonging to Nervilia. Fresh specimens were collected and dissected for thorough analysis based on studying the available relevant literature (Seidenfaden \& Wood, 1992; Averyanov, 2008, 2010, 2011a,b, 2013; Chen \& Gale, 2009; Hsu et al., 2012; Jalal

Received: 16.05.2021; Revised \& Accepted: 17.09.2021

Published Online: 16.10 .2021 et al., 2012; Gale et al., 2013, 2014, 2015, 2016; Lin \& Chang, 2013; Gale \& Watthana, 2014; Lin, 2014) and herbarium specimens in PDA, along with other repositories of online digital specimens at K and P. In Sri Lanka, Nervilia was known to be represented by a single species, $N$. juliana (Roxb.) Schltr., but its occurrence was believed to be doubtful (Hooker, 1898; Jayaweera, 1981; Fernando \& Ormerod, 2008). Hooker (1898) pointed out that at PDA there are multiple specimens under the name Pogonia juliana Roxb. (三Nervilia juliana) but they vary significantly from the specimens of $P$. juliana, owing to the "orbicular leaf with multiple radiating veins". In a recent publication, de Vlas (2019) reported three species of Nervilia, namely, N. plicata (Andrews) Schltr., N. concolor (Blume) Schltr. and N. crociformis (Zoll. \& Moritzi) Seidenf., that were not reported before from Sri Lanka, however, the author did not document the occurrence of $N$. juliana in this country. The three species found during the current study matched with those of de Vlas (2019). Here we review their taxonomy, type status, global distribution and habitat ecology (Fig. 1), and present notes on their phenology, colour illustrations and line drawings (Figs. 2-8). The historic specimens of this genus placed under $N$. juliana were consulted to confirm their identity. A key to aid identification for the genus in Sri Lanka is provided. All specimens are deposited at PDA. Nomenclature follows Govaerts et al. (2021). 

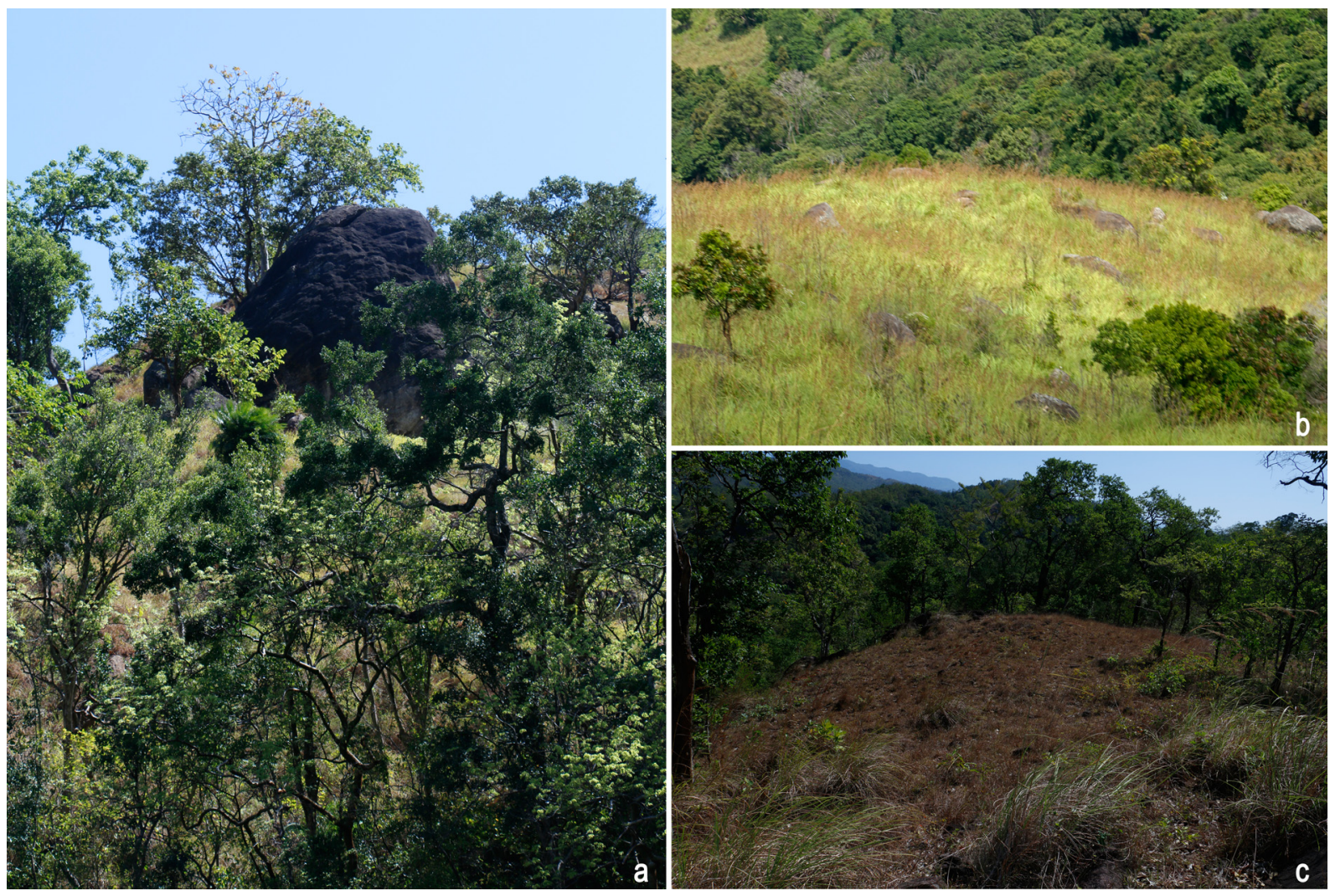

Fig. 1. Habitats of Nervilia Comm. ex Gaudich. in Sri Lanka. a. Kalthota; b. Ella; c. Nilgala (photos by A.G. Atthanagoda).

\section{Taxonomic Treatment}

Nervilia Comm. ex Gaudich., Voy. Uranie 422. 1829, nom. cons. Type: Nervilia aragoana Gaudich. (=Nervilia concolor (Blume) Schltr.)

Cordyla Blume, Bijdr. Fl. Ned. Ind. 416.1825, nom. illeg.

Aplostellis A.Rich., Mém. Soc. Hist. Nat. Paris 4: 36. 1828.

Roptrostemon Blume, Fl. Javae, Praef. vi. 1828.

Haplostellis Endl., Gen. Pl. 219. 1837.

Rophostemon Endl., Gen. Pl. 216. 1837, orth. var. Bolborchis Zoll. \& Moritzi in A.Moritzi, Syst. Verz. Java 89. 1846.

Terrestrial herbs with an underground, white, globose, multi-noded corm from which the floral shoot emerges before the emergence of the leaf. Leaf solitary, plicate with cordate base and almost always acute apex (rarely rounded); either raised on an elongated petiole above ground or adpressed tightly or loosely on the ground. Inflorescence may bear 1, 2 or more than 2 flowers. Flowers may or may not open widely; petals and sepals similar, usually linear-lanceolate; lip usually 3-lobed, rarely entire, side lobes raised, encircling the column; column long, clavate; anther 2-locular, pollinia 2, sectile, granular, caudicle absent (Pridgeon et al., 2005; Chen \& Gale, 2009; Cribb \& Whistler, 2011). Schlechter (1911) originally created three sections that were also followed by Pridgeon et al. (2005), namely, Nervilia s.s., Vinerlia Schltr. and Linervia Schltr.

\section{Key to the species of Nervilia in Sri Lanka}

1. Leaf raised above ground on a long petiole like stalk, inflorescence with multiple flowers...... N. concolor

1. Leaf placed on ground (without elongated petiole), inflorescence with 1 or 2 flowers..... 
2. Leaf hairy, inflorescence 2-flowered (rarely 1), lip longitudinally folded and with an entire margin (slightly emarginated at apex) N. plicata

2. Leaf glabrous, inflorescence 1-flowered, lip not folded and with a fimbriate margin .... N. simplex

Nervilia concolor (Blume) Schltr., Bot. Jahrb. Syst. 45(3): 404. 1911. Cordyla concolor Blume, Bijdr. Fl. Ned. Ind. 416.1825. Roptrostemon concolor (Blume) Lindl., Gen. Sp. Orchid. Pl. 453. 1840. Pogonia concolor (Blume) Blume, Mus. Bot. 1: 32. 1849. Type: JAVA, Mt. Salak, Blume s.n. (holo L-cannot be located).

Nervilia aragoana Gaudich., Voy. Uranie 422. 1829.

Epipactis carinata Roxb., Fl. Ind. 3: 454. 1832. Pogonia carinata (Roxb.) Lindl., Gen. Sp. Orchid. Pl.: 414. 1840. Nervilia carinata (Roxb.) Schltr., Bot. Jahrb. Syst. 45: 404. 1911.

Pogonia flabelliformis Lindl., Gen. Sp. Orchid. Pl. 415. 1840. Aplostellis flabelliformis (Lindl.) Ridl., Fl. Malay Penins. 4: 203. 1924. Nervilia flabelliformis (Lindl.) Tang \& F.T.Wang, Acta Phytotax. Sin. 1: 68. 1951.

Pogonia nervilia Blume, Mus. Bot. 1: 32. 1849. nom. superfl.

Pogonia gracilis Blume, Coll. Orchid.: 155. 1858.

Pogonia scottii Rchb.f., Flora 55: 276. 1872. Nervilia scottii (Rchb.f.) Schltr., Bot. Jahrb. Syst. 45: 404. 1911.

Nervilia yaeyamensis Hayata, Icon. Pl. Formosan. 2: 140.1912.

Nervilia tibetensis Rolfe, Notes Roy. Bot. Gard. Edinburgh 8: 128. 1913.

Figs. 2a-c, 3 \& 4

Tuber spherical or ovoid, $1.5-2.5 \mathrm{~cm}$ in diameter, white, with multiple nodes. Leaf green, sometimes with purple blotches, broadly cordate, $8-12 \mathrm{~cm}$ long, 8-15 cm wide, strongly plicate, glabrous, many veined, acute to shortly acuminate, shallowly crenate, undulate along margin. Petiole 12-20 cm long, usually with 1-2 short tubular sheaths near base. Inflorescence erect, bearing 3-16 flowers; peduncle with 2-4 tubular sheaths. Floral bracts reflexed, narrowly lanceolate, $0.9-1.7 \mathrm{~cm}$ long, 1$1.5 \mathrm{~mm}$ wide, longer than ovary. Flowers pendent, resupinate, usually not widely open, scented. Pedicelled ovary $0.7-1.3 \mathrm{~cm}$ long, ridged. Dorsal sepal lanceolate, acute, greenish-white, 14.5-17 $\mathrm{mm}$ long, 2-3 mm wide. Lateral sepals and petals similar in shape, linear-lanceolate, acute, greenish. Lateral sepals $12.5-16 \mathrm{~mm}$ long, 2-3 mm wide. Petals 14-18 mm long, 2-3 mm wide. Lip pale green to white, often with purplish-brown venation, purple-violet blotched at apex, shape variable, ovate-oblong, obovate, or rhombic, 11$14 \mathrm{~mm}$ long, 5-7 mm wide, spur absent, 3-lobed; lateral lobes small, erect, triangular, acute, loosely embracing column; mid-lobe ovate, ovate-elliptic or ovate-triangular, obtuse; disk villous primarily on veins and at apex. Column white, 6-8 mm long. Flowering \& fruiting: Flowering from April to August. fruiting from May to August.

Habitat: Terrestrial herbs, growing in moist mixed evergreen forests and Savanna grasslands. Mostly prefers shady places among short grasses at 200$1100 \mathrm{~m}$ elevation. Total population size in Sri Lanka is estimated to comprise fewer than 100 mature individuals. Locally rare.

Distribution: Bangladesh, Bhutan, Bismarck Islands, Borneo, Caroline Island, China, Cook Island, India, Japan, Java, Laos, Lesser Sunda Island, Malaku, Malaya, Marianas, Myanmar, Nepal, New Caledonia, New Guinea, Niue, Northern Territory-Australia, Pakistan, Philippines, Queensland, Samoa, Society Island, Solomon Islands, Sri Lanka, Sulawesi, Sumatera, Taiwan, Thailand, Tonga, Vanuatu, Vietnam and WallisFutuna Island.

Specimens examined: INDIA, Orissa, Ganjam, Mohana, S. Misra 114 (CAL). South Andaman, N.P. Balakrishnan 4086 (CAL). Sikkim, 2500 feet, 05.1891, R. Pantling 143 (P [P00347511]). INDONESIA, Lesser Sunda Islands, Kandang, 800 m, 01.10.1980, E. Schmutz 4703 (L 


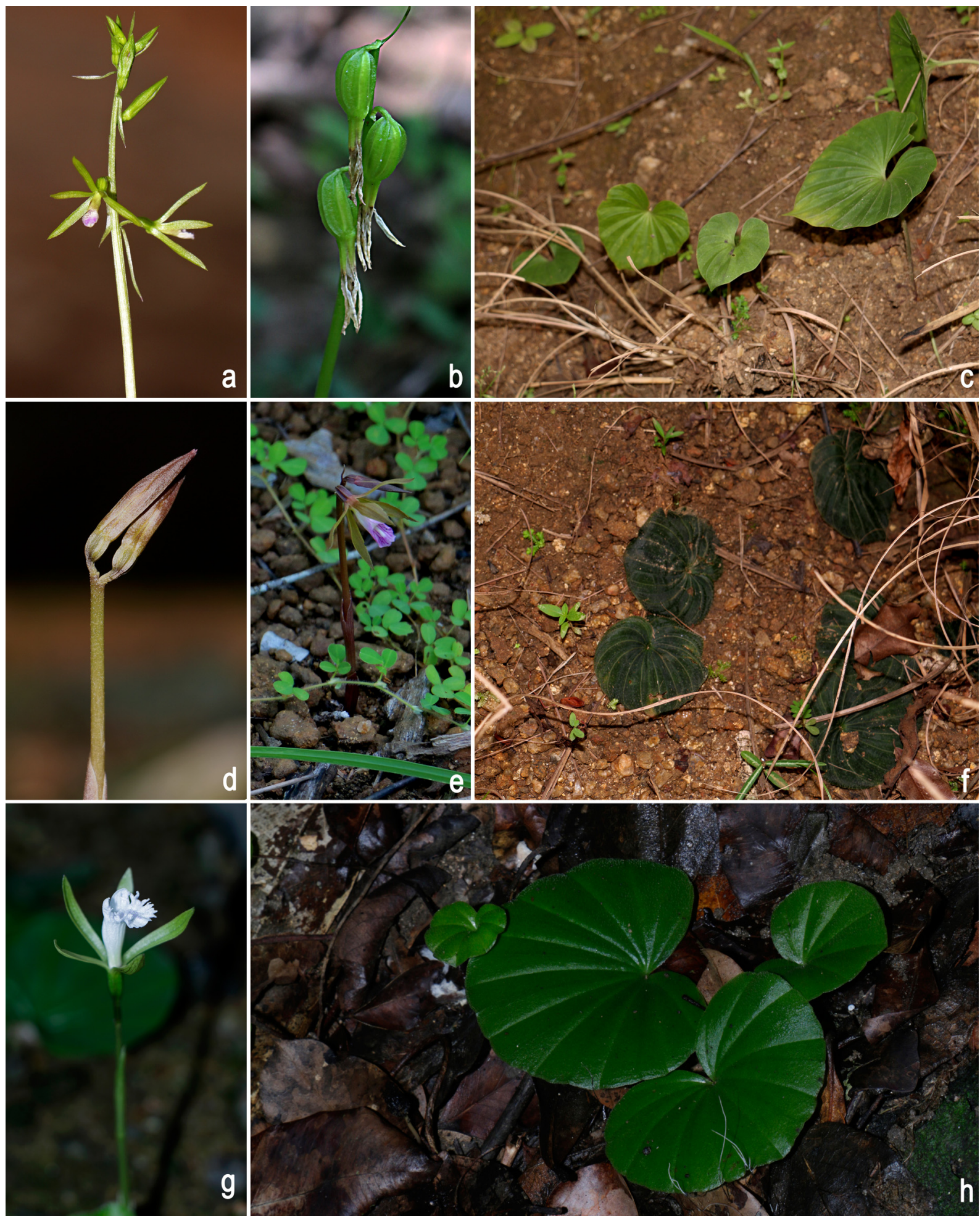

Fig. 2. Photographic images of Nervilia spp.: a-c. N. concolor (Blume) Schltr.: a. Flowers; b. Fruits; c. Leaves; d-f. N. plicata (Andrews) Schltr.: d. Flower buds; e. Flowers; f. Leaves; g,h. N. simplex (Thouars) Schltr.: g. Flower; h. Leaves (a-c from AKAG 13 (PDA); d-f from AKAG 11 (PDA); g-h from AKAG 12 (PDA); photos by A.G. Atthanagoda).

[L1514232]). LAOS, Salavan, 13.04.1927, E. Poilane 13754 (P [P00347528]). SRI LANKA, Bulupitiya, near Nilgala, Bibile, 20.04.2009, AKAG 37; ibid., 25.05.2009, AKAG 13;
Kitugala, rainforest next to rubber plantation, 06.06.2010, AP 2011/04/04 (PDA). THAILAND, Chiang Mai, Jawn Tong, Mae Soi Valley, 11.05.1990, J.F. Maxwell 90-494 (L [L1517282]). 


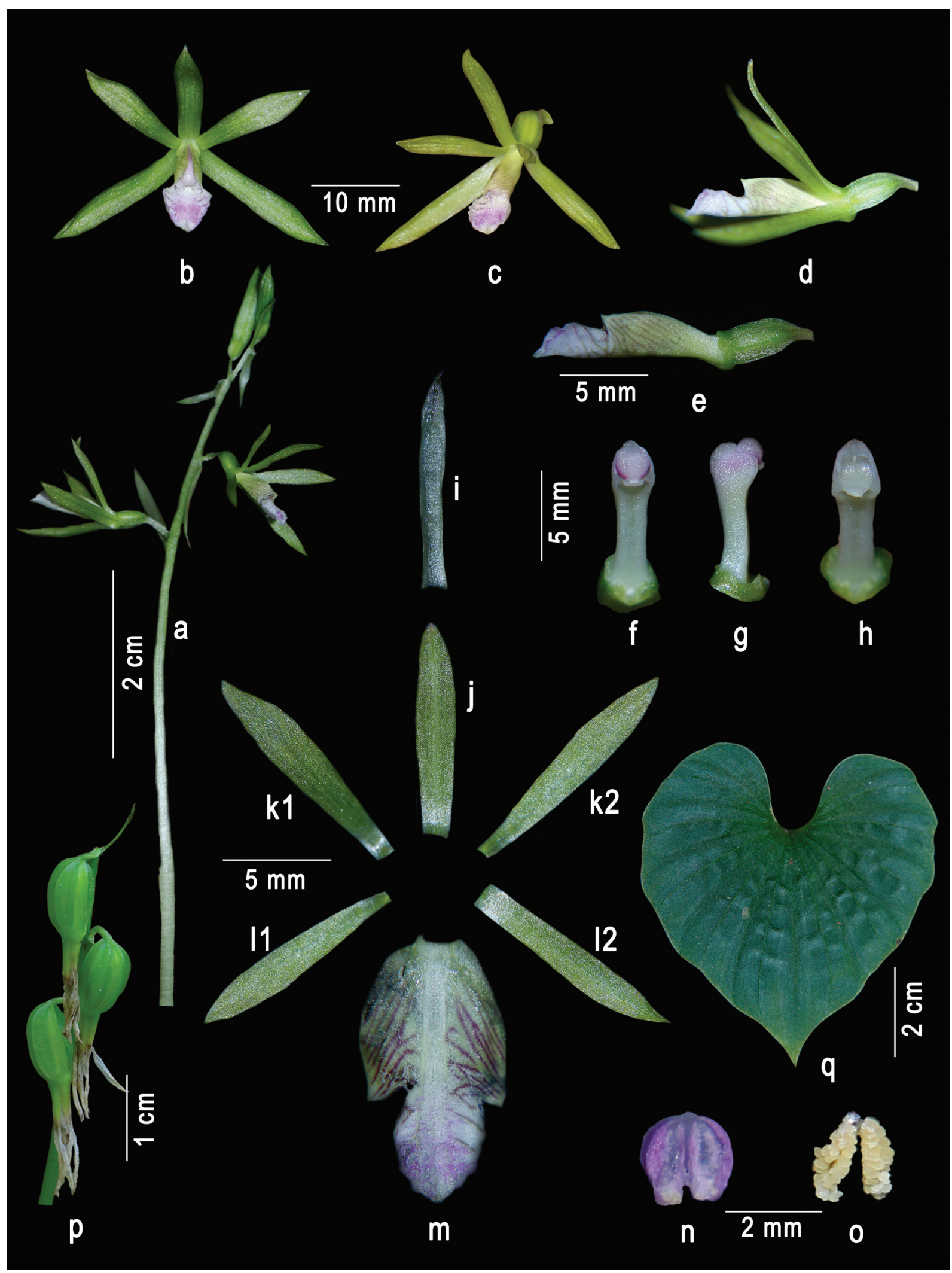

Fig. 3. Photographic images of Nervilia concolor (Blume) Schltr.: a. Inflorescence; b. Flower-front view; c. Flower-abaxial view; d. Flowerlateral view; e. Ovary and lip-lateral view; f. Column-front view; g. Column-lateral view; h. Column without anther cap; i. Bract; j. Dorsal sepal; k1 \& k2. Lateral sepals; I1 \& 12. Petals; m. Lip; n. Adaxial view of anther cap; 0. Pollinia; p. Fruits; q. Leaf (from AKAG13 (PDA); photos by A.G.Atthanagoda). 


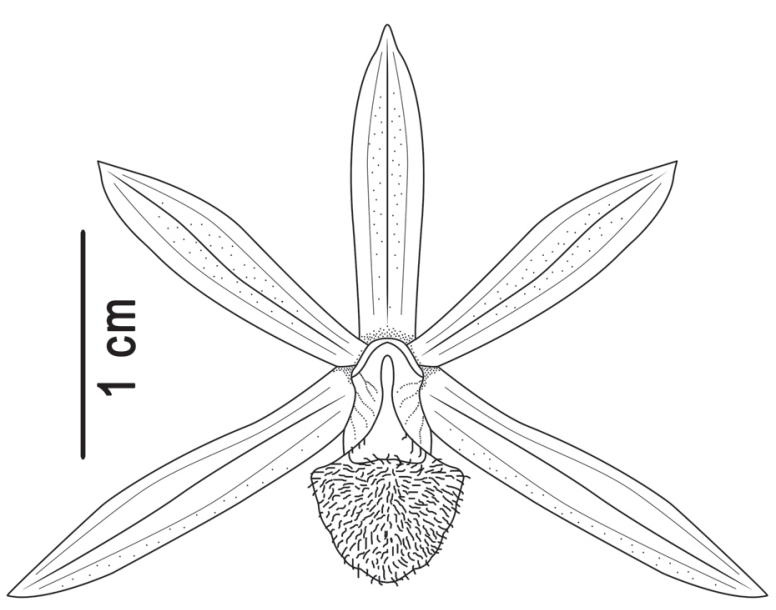

C

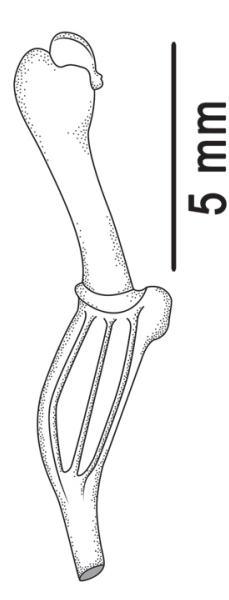

d

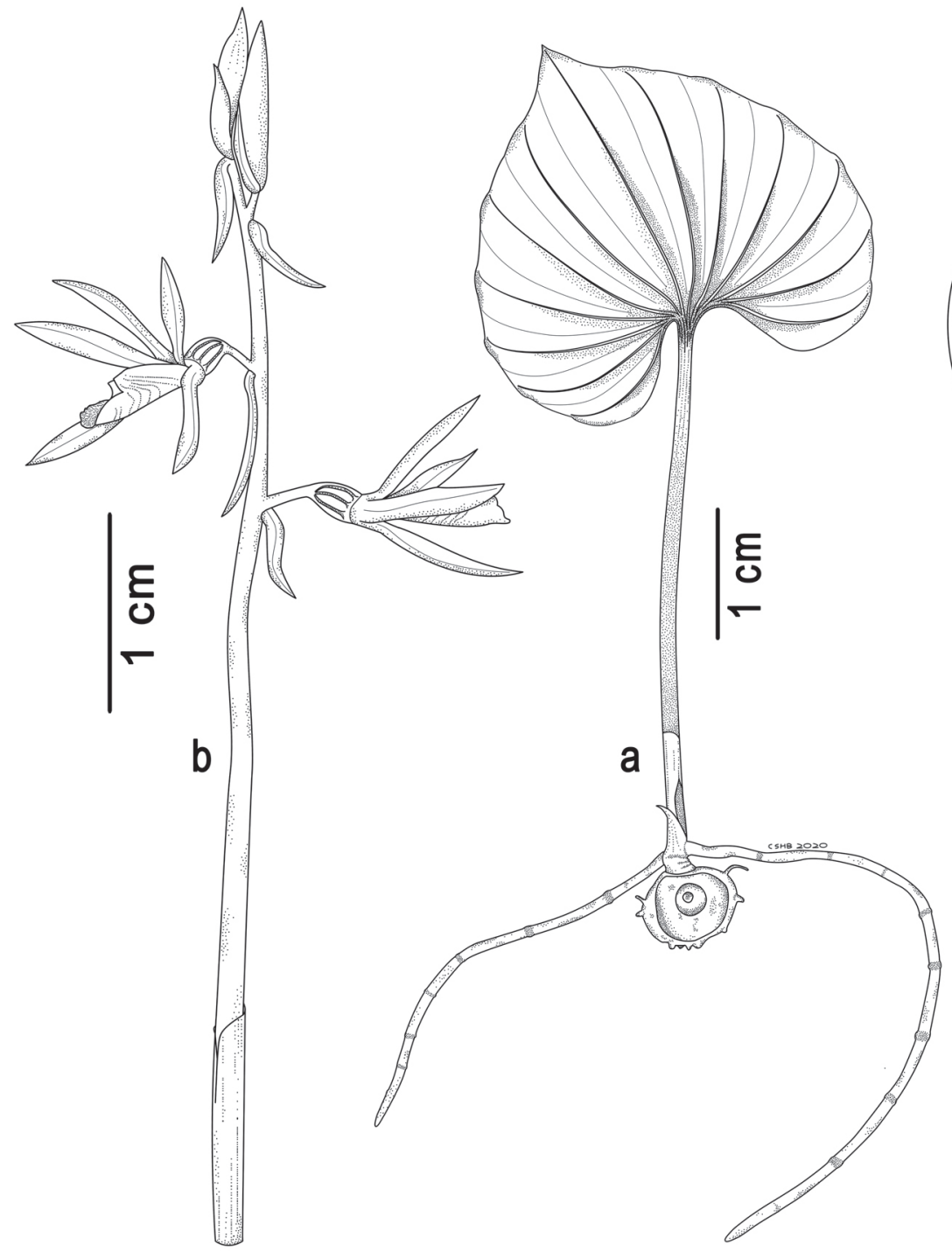

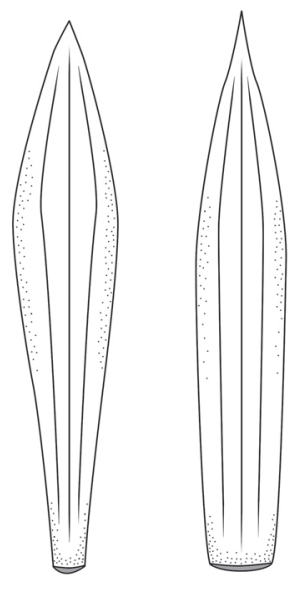

g

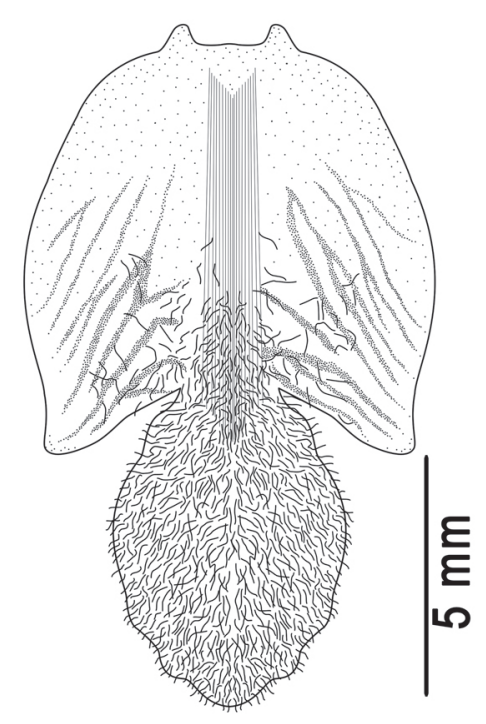

h

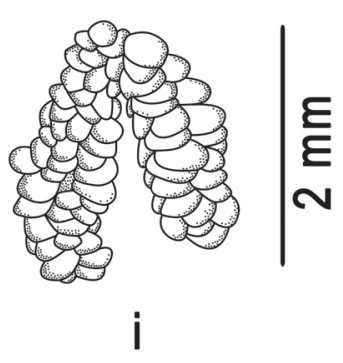

Fig. 4. Drawings of Nervilia concolor (Blume) Schltr.: a. Plant; b. Inflorescence; c. Flower-front view; d. Column with ovary; e. Dorsal petal; f. Lateral sepal; g. Petal; h. Lip; i. Pollinia (from AKAG13 (PDA); drawn by C. Bandara). 
Vietnam, Nun Bara Province, Bienhoa, 23.04.1930, E. Poilane 17345 (P [P00347526]).

Notes: In PDA, a specimen deposited from Kitulgala in Sabaragamuwa province (AP.2011/04/04) with a leaf and two flower stalks is identified as Nervilia concolor. However, the species was not found during recent field visits to the Kitulgala area.

Cribb and Whistler (2011) cited Blume s.n. as the holotype of this name and claimed that it is present at L. However, Seidenfaden (1978) was unable to locate it. Further research is needed to confirm whether or not type material still exists. In the absence of type material, the name would need to be neotypified, but due to lack of information and access to original (or related) materials, it was not attempted in the current study.

Nervilia plicata (Andrews) Schltr., Bot. Jahrb. Syst. 45: 403. 1911. Arethusa plicata Andrews, Bot. Repos. 5: t. 321. 1803. Epipactis plicata Roxb., Fl. Ind. 3: 454. 1832. Pogonia plicata (Andrews) Lindl., Gen. Sp. Orchid. Pl. 415. 1840. Lectotype (designated here): Andrews, Bot. Repos. 5: t. 321. 1803. (plate 321 is based on the collection, A.B. Lambert s.n., from East India in 1803).

Cordyla discolor Blume, Bijdr. Fl. Ned. Ind. 416. 1825.

Pogonia biflora Wight, Icon. Pl. Ind. Orient. 5: t. 1758. 1851.

Pogonia dallachyana F.Muell. ex Benth., Fl. Austral. 6: 310.1873.

Pogonia velutina C.S.P.Parish \& Rchb.f., Trans. Linn. Soc. London 30: 142. 1874.

Pogonia pulchella Hook.f., Bot. Mag. 111: t. 6851. 1885.

Nervilia apiculata Schltr., Repert. Spec. Nov. Regni Veg. Beih. 1: 41. 1911.

Nervilia porphyrophylla Schltr., Repert. Spec. Nov. Regni Veg. Beih. 1: 41. 1911.

Pogonia purpurea Hayata, J. Coll. Sci. Imp. Univ. Tokyo 30(1): 345. 1911.

Figs. 2d-f, 5 \& 6

Tuber spherical or ovoid, $1-2.5 \mathrm{~cm}$ in diameter.
Leaf almost orbicular, broadly cordate at base, apex obtuse to almost rounded, 8-10 cm long, $8-12 \mathrm{~cm}$ wide, dark green to dark brown-purple, sometimes with darker blotches, many veined, pubescent, particularly along veins. Petiole erect, $2-4 \mathrm{~cm}$ long. Inflorescence $4-16 \mathrm{~cm}$ tall, 2-flowered, rarely 1 or 3; peduncle with 2-3 tubular sheaths. Floral bracts cuneate, acuminate, 3-7 mm long, about $1.5 \mathrm{~mm}$ wide. Flowers nodding, resupinate, widely opening. Pedicelled ovary 5-8 mm long, ridged. Sepals, petals similar, light pale brownish-yellow, lanceolate, acute, petals $2-3.5 \mathrm{~cm}$ long, $3.5-4.5 \mathrm{~mm}$ wide, sepals $2.5-3.5 \mathrm{~cm}$ long, 3-4 mm wide. Lip white, light yellowish-brown or light purple-violet, with yellow median stripe and light purple-red venation at the sides, entire, oblong-ovate, 12-16 mm long, 9-14 mm wide, spur absent, loosely embracing column at base; lip apex almost round or slightly emarginate; disk glabrous, with median ridge running from base to apex. Column clavate, 8-10 mm long, 3-4 mm wide, white; anther cap subquadrate; stigma suborbicular.

Flowering \& fruiting: Flowering from February to May, fruiting from February to June.

Habitat: Terrestrial orchid growing in moist mixed evergreen forests and savanna grasslands. Mostly prefers shady places among short grasses at around 200-1100 m elevation. Recent field observations indicate that each subpopulation consists of 25-30 individuals. Locally rare.

Distribution: Bangladesh, Bhutan, India, Indonesia, Laos, Malaysia, Myanmar, New Guinea, Philippines, Sri Lanka, Thailand, Taiwan and Vietnam in Asia; Australia.

Specimens examined: INDIA, 1869, E.C. Parish 182 (K [K000387598]). SRI LANKA, Appalagala OSF, Balangoda Range, Belihuloya Beat, 20.03.1994, A.H.M. Jayasuriya 8173; Koslanda, Akkaraseeya, 18.03.2008, S.coll. AP.2011/04/01; Beragala, 20.03.2009, S.coll. AP.2011/04/02: plant with larger leaf and flower stalk on the lower side of the sheet belongs to $N$. plicata, while the specimen with smaller leaf in the upper part belongs to N. simplex); 


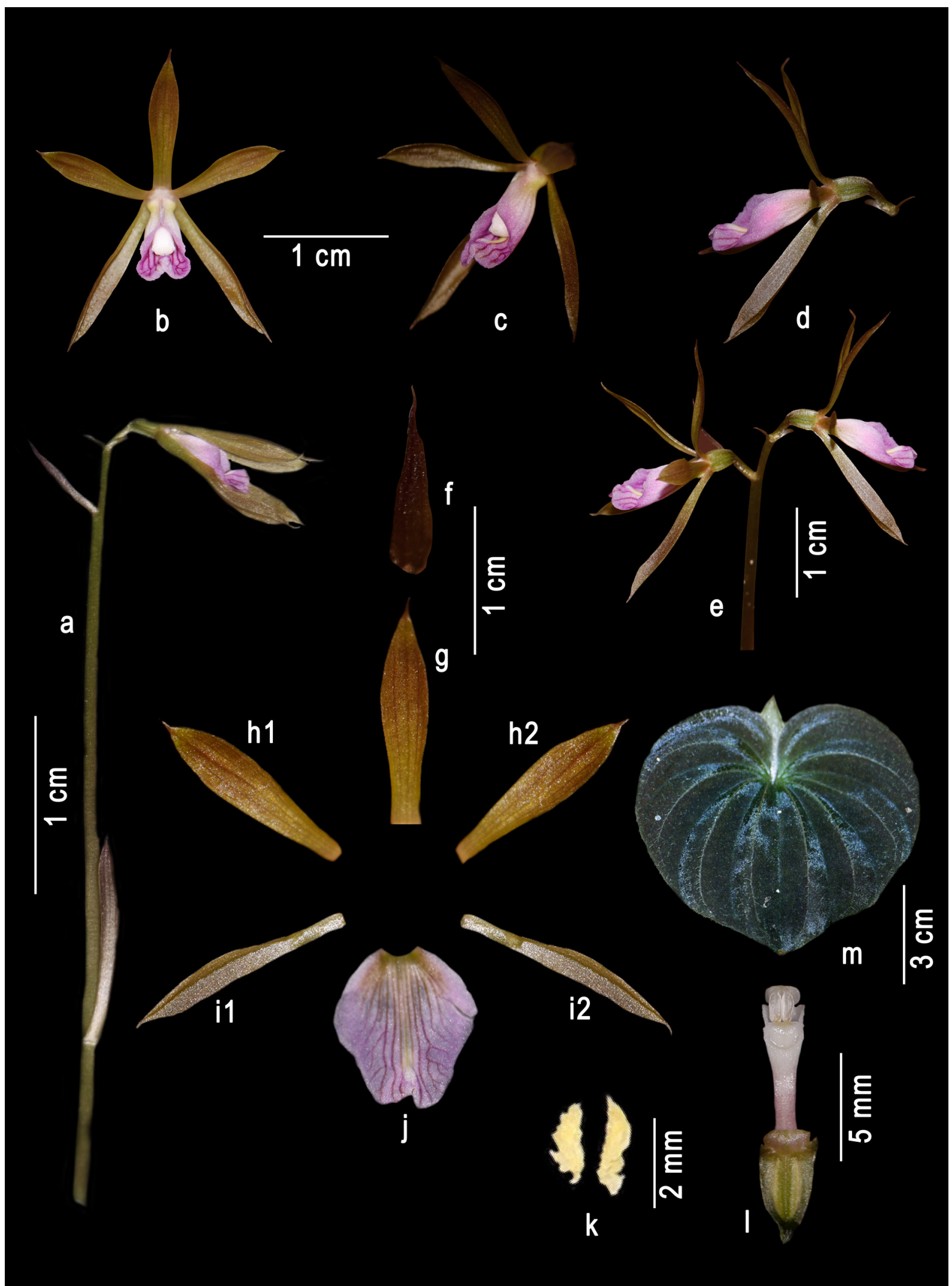

Fig. 5. Photographic images of Nervilia plicata (Andrews) Schltr.: a. Inflorescence; b. Flower-front view of flower; c. Flower-abaxial-lateral view; d. Flower-lateral view; e. 2-flowered inflorescence; f. Bract; g. Dorsal sepal; h1 \& h2. Lateral sepals; i1 \& i2. Petals; j. Lip; k. Pollinia; I. Ovary and column-front view; m. Leaf (from AKAG11 (PDA); photos by A.G. Attahanagoda). 


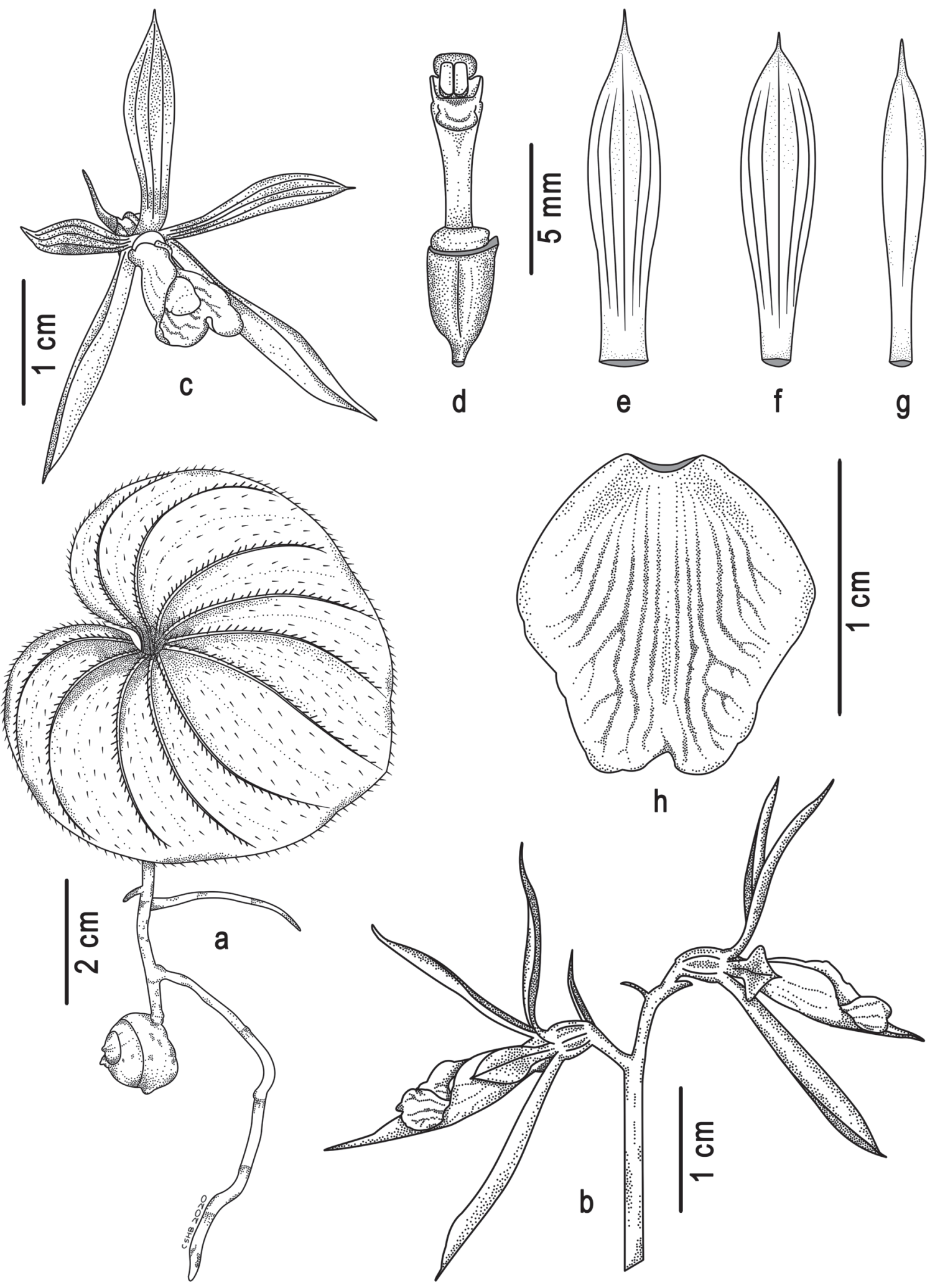

Fig. 6. Drawings of Nervilia plicata (Andrews) Schltr.: a. Plant; b. Flowers; c. Flower-oblique front view; d. Column with ovary; e. Dorsal sepal; f. Lateral sepal; g. Petal; h. Lip (from AKAG 11 (PDA); drawn by C. Bandara). 
Bulupitiya, near Nilgala, Bibile, 25.05.2009, AKAG 11; Ibid., 20.04.2009, AKAG 35; Ibid., 20.04.2009, AKAG 36 (PDA).

Notes: A specimen (A.H.M. Jayasuriya 8173) of this species (leaf only), collected from Belihuloya area in Sabaragamuwa Province and bearing a note "leaves purple", was deposited in PDA under the name N. juliana (Roxb.) Schltr.. Field observations in China, India, Laos and Sri Lanka have revealed that the leaf colour varies in this species from green to reddish-purple and sometimes they are even variegated with green-light green-reddish purple.

After repeated searches, the type for this name could not be located at K. It is assumed to have been lost, in which case a lectotype is needed for this name. Seidenfaden (1978) also indicated his doubt about the existence of the type and suggested that the Andrew's illustration (Andrew, 1803) should be considered as type. However, he did not formally designate a lectotype. The illustration, t. 321, in Andrews (1803) was based on "the plants flowering at the hot-house of J. Vere, Esquire, Kensington Gore, in the month of July". This collection, as per the protologue, has come from Aylmer Bourke Lambert who originally sent it to England in 1803 from India. Hence, being based on original material, this plate is designated as the lectotype.

Nervilia simplex (Thouars) Schltr., Bot. Jahrb. Syst. 45 (3): 401. 1911. Arethusa simplex Thouars, Hist. Orchid.: t. 24. 1822. Epidendrum simplex (Thouars) Spreng., Syst. Veg. 3: 736. 1826. Pogonia simplex (Thouars) Rchb.f., Xenia Orchid. 2: 92. 1865. Aplostellis simplex Thouars, Hist. Orchid.: t. 24. 1822. Lectotype (designated by Pettersson, 1991): MAURITIUS, s.loc., 1793-1796, Thouars, Maurice, Orch. Îles Austr. Afr.: t. g. Icon. 24. 1822. Stellorkis aplostellis Thouars, Hist. Orchid.: t. 24. 1822.

Bolborchis crociformis Zoll. \& Moritzi in A.Moritzi, Syst. Verz. Java: 89. 1846.

Pogonia crispata Blume, Mus. Bot. 1: 32.1849.
Pogonia prainiana King \& Pantl., J. Asiat. Soc. Bengal, Pt. 2, Nat. Hist. 65: 129. 1896.

Coelogyne javanica Lindl., Fol. Orchid. 5: 17. 1854.

Pogonia thouarsii Blume, Coll. Orchid.: 152. 1859.

Pogonia bollei Rchb.f., Xenia Orchid. 2: 88. 1865.

Nervilia fimbriata Schltr. in K.M.Schumann \& C.A.G.Lauterbach, Fl. Schutzgeb. Südsee, Nachtr.: 82. 1905.

Nervilia humilis Schltr., Bot. Jahrb. Syst. 53: 551. 1915.

Nervilia reniformis Schltr., Bot. Jahrb. Syst. 53: 551. 1915.

Nervilia francoisii H.Perrier, Bull. Trimestriel Acad. Malgache, n.s., 21: 304. 1928.

Nervilia monantha Blatt. \& McCann, J. Bombay Nat. Hist. Soc. 35: 724. 1932.

Nervilia bathiei Senghas, Adansonia Ser. 2, 4: 303. 1964.

Nervilia erosa P.J.Cribb, Kew Bull. 32: 155. 1977.

Figs. $2 \mathrm{~g}-\mathrm{h}, 7$ \& 8

Tuber subglobose to ovoid, about $1-2 \mathrm{~cm}$ in diameter, white. Leaf pale green, shallowly crenulate-polygonal, cordate at base, 7-9 cm long, 4-6 cm wide, slightly fleshy, sparsely setulose above, commonly with 7 main prominent veins, often slightly undulate along margin. Petiole erect, 1$3(5) \mathrm{cm}$ long. Inflorescence erect, 4-7 cm tall, 1flowered; peduncle with 2-3 tubular scarious sheaths. Floral bract small, ovate to lanceolate, acute. Flower erect, not resupinate, opening widely, 2-4 $\mathrm{cm}$ across. Sepals and petals similar, lanceolate, light green; sepals 2-2.5 cm long, 1.2-2.5 mm wide, acute to acuminate; petals $1.8-2.3 \mathrm{~cm}$ long, 1-2 $\mathrm{mm}$ wide. Lip with strongly reflexed epichile, white, tinted green towards base, sometimes with yellowish spot at centre, rhombic, 15-18 mm long, 8-13 mm wide when flattened, spurless, entire or 3-lobed, lateral margins erect, loosely embracing column; apical margin irregularly lacerate or fimbriate; disk with low papillose ridge extending from lip base to apex. Column clavate, $6-8 \mathrm{~mm}$ long; stigma suborbicular. 


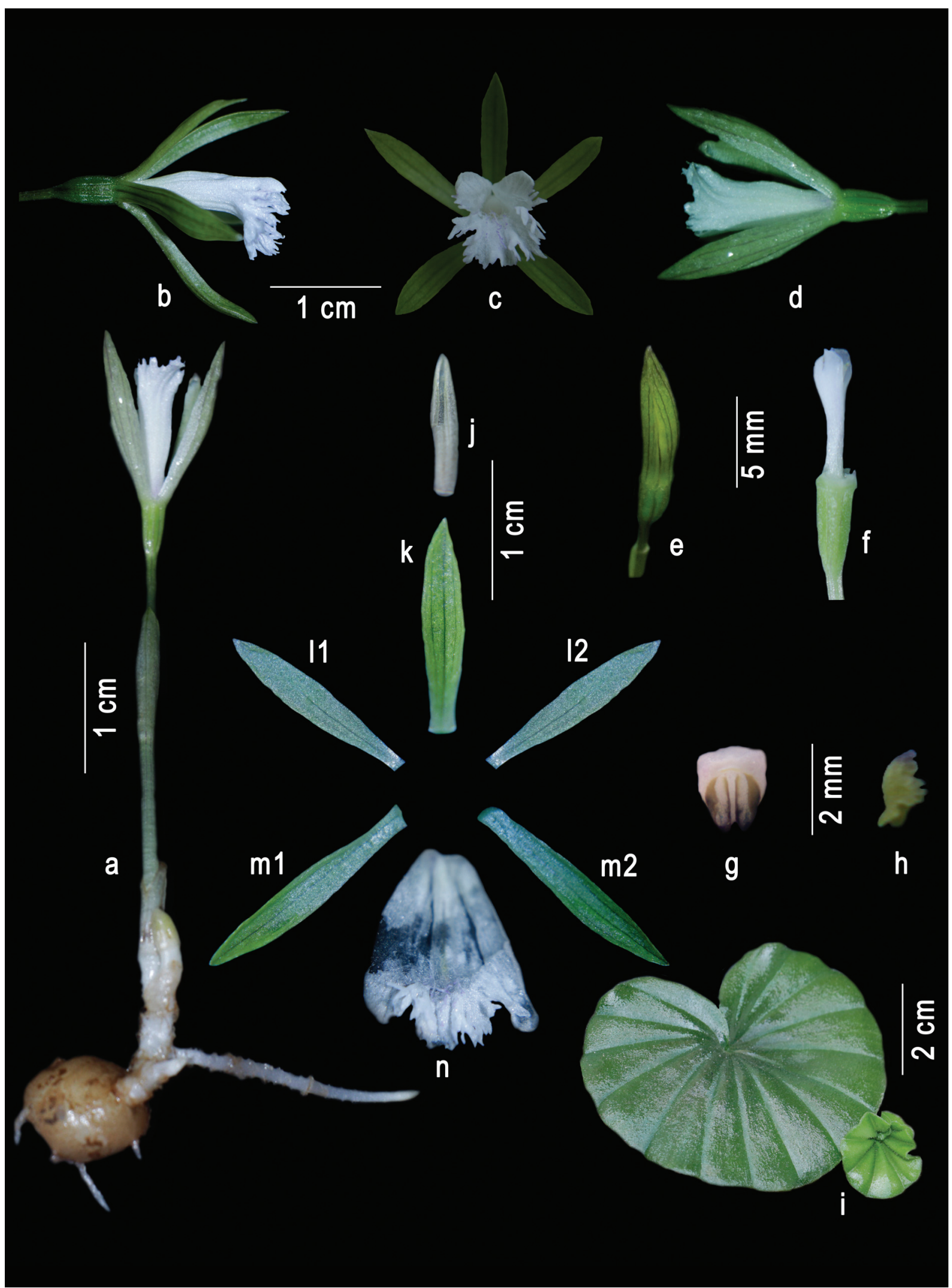

Fig. 7. Photographic images of Nervilia simplex (Thouars) Schltr.: a. Plant with erect flower; b. Flower-lateral view; c. Flower-front view; d. Flower-adaxial view; e. Flower bud; f. Ovary \& column-side view; g. Anther cap-adaxial view; h. Pollinia; i. Leaves (of two different plants); j. Bract; k. Dorsal sepal; I1 \& 12. Lateral sepals; m1 \& m2. Petals; n. Lip (from AKAG 12 (PDA); photos by A.G. Atthanagoda). 


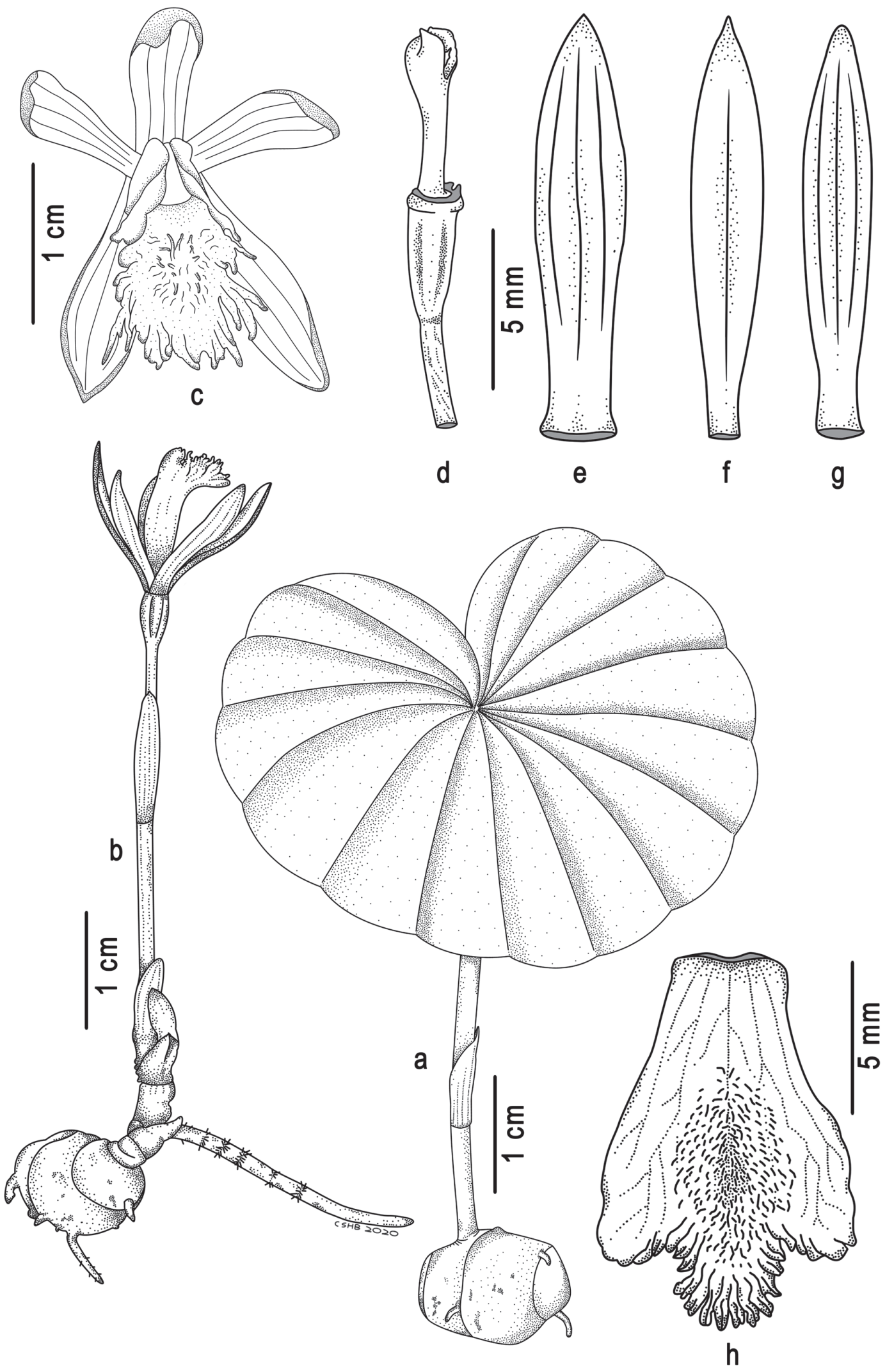

Fig. 8. Drawings of Nervilia simplex (Thouars) Schltr.: a. Plant; b. Plant in flower; c. Flower-front view; d. Column with ovary; e. Dorsal petal; f. Lateral sepal; g. Petal; h. Lip (from AKAG 12 (PDA); drawn by C. Bandara). 
Flowering: Flowering from May to September at the Nilgala subpopulation and in November at the Kalthota and Belihuloya subpopulations. Flowers open in the morning, emitting an unpleasant odour, and wither within a few hours. Fruiting not observed.

Habitat: In shady places in understorey and among short grasses, growing in loose, humus-rich soil, sometimes on banks of streams. Locally very rare.

Distribution: India, Indonesia, Malaysia, Nepal, New Guinea, Philippines, Sri Lanka, Thailand, Taiwan and Vietnam in Asia; Africa; Australia.

Specimens examined: INDIA, Sikkim, Lachoong Valley, July 1895, R. Pantling 372 (BM [BM000061415]). NIGERIA, Ibadan Ogbomosho Forest Reserve, Olla hills, 01.04.1958, A. Binuyo 36921 (P [P00353521]). SRI LANKA, Koslanda, Beragala, 20.03.2009, AP.2011/04/02 (PDA: this voucher contains multiple specimens, those with smaller leaves belong to $N$. simplex); Bulupitiya, near Nilgala, Bibile, 25.05. 2009, AKAG 12; Ibid., 20.04.2009, AKAG 23 (PDA). TANZANIA, Nyassa Hochland, Station Kyimbila, 17.12.1912, A. Stolz 1791 (K [K000306638]). ZAMBIA, South of Mwinilunga, October 1970, Drummond Williamson s.n. (K [K000306637]).

\section{Notes on the occurrence of Nervilia juliana (Roxb.) Schltr. in Sri Lanka}

Thwaites (1864) wrote on the occurrence of Pogonia juliana (Roxb.) Wall. ex Trimen (Nervilia juliana (Roxb.) Schltr.) in Sri Lanka and mentioned the drawing CP 3841. Hooker (1898) mentioned the existence of this drawing (CP 3841; a flowering specimen without leaves) at PDA, however, he had his doubts about the identification of this plant. He also indicated the presence of other specimens with leaves (only). These leaves were "orbicular with many radiating veins". He again had doubts about the identity, but he followed "Thwaites and Trimen's catalogues". Fernando and Ormerod (2008) indicated their doubts about the occurrence of this species in Sri Lanka. At PDA we multiple specimens of A.H.M. Jayasuriya 8173, which contained only a single leaf on each specimen, collected from Belihuloya area in Sabaragamuwa province and bearing a note "leaves purple", and was labelled as $N$. juliana. However, this is not the specimen that the authors have talked about historically as it was collected in 1994. We are sure that these specimens belong to N. plicata owing to the typical character of the species as mentioned above in the description. As such, current authors or previous authors have not seen a single authentic specimen of $N$. juliana from Sri Lanka in the field or at PDA, neither have they been able to find the drawing (CP 3841). Hence, we conclude that $N$. juliana does not occur in Sri Lanka.

\section{Acknowledgements}

The authors are especially grateful to Dr. R.A.S.W. Ranasinghe and the staff of National Herbarium, Royal Botanic Garden, Peradeniya for their generosity and cooperation in facilitating specimen loans. The authors are also thankful to André Schuiteman, Royal Botanic Gardens, Kew, for his valuable help and suggestion. We owe thanks to Kasun Munasinghe, Dushantha Chathuranga, Sanath Bandara Herath, Buwaneka S. Pathirana, Lasantha Aberathna, Mahanama Kushalya, Kanishka M. Gunathunga and Tharaka S. Priyadarshana for their support in the field.

\section{Literature Cited}

ANDREW H.C. 1803. The botanist's repository, for new and rare plants. Volume 5. T. Bensley and H.C. Andrews.

AVERYANOV L. 2008. The orchids of Vietnam. Illustrated survey. Part 1. Subfamilies Apostasioideae, Cypripedioideae and Spiranthoideae. Turczaninowia 11: 5-168.

AVERYANOV L. 2010. The orchids of Vietnam. Illustrated survey. Part 2. Subfamily Orchidoideae. Turczaninowia 13: 5-98.

AVERYANOV L. 2011a. Nervilia gracilis - a new orchid species from northern Vietnam. Taiwania 56: 50-53. https:/doi.org/10.6165/tai.2011.56(1).50

AVERYANOV L. 2011b. The orchids of Vietnam. Illustrated survey. Part 3. Subfamily Epidendroideae (primitive tribes Neottieae, Vanilleae, Gastrodieae, Nervilieae). Turczaninowia 14: 15-100. 
AVERYANOV L. 2013. The orchids of Vietnam. Illustrated survey. Part 4. Subfamily Epidendroideae (tribes Arethuseae and Malaxideae). Turczaninowia 16: 5-163.

CHEN S.C. \& S.W. GALE 2009. Nervilia. In: WU Z.Y., P.H. RAVEN, \& D.Y. HONG (eds.), Flora of China. Science Press, Beijing and Missouri Botanical Garden Press, St. Louis. pp. 197-201.

CRIBB P.J. \& A. WHISTLER 2011. The Orchids of Tonga, Niue, and the Cook Islands. Lankesteriana 11: 96-177.

DE VLAS J. 2019. Illustrated Field Guide to the Flowers of Sri Lanka.Volume 3. Jacob de Vlas, Sri Lanka.

FERNANDO S.S. \& P. ORMEROD 2008. An annotated checklist of the orchids of Sri Lanka. Rheedea 18: 1-28.

GALE S.W. \& S. WATTHANA 2014. Nervilia. In: PEDERSEN H., H. KURZWEIL, S. SUDDEE, E.F. DE VOGEL, P.J. CRIBB, S. CHANTANAORRAPINT, S. WATTANA, S.W. GALE, T. SEELANAN \& C. SUWANPHAKDEE (eds.), Flora of Thailand, Volume 12(2). Forest Herbarium, Department of National Parks, Wildlife and Plant Conservation, Bangkok. pp. $553-569$.

GALE S.W., SUDDEE S. \& S. WATTHANA 2013. Studies in Asian Nervilia (Orchidaceae) III: N. khaoyaica, a new species from eastern Thailand. Kew Bulletin 68: 331335. https://doi.org/10.1007/s12225-013-9438-0

GALE S.W., RUEANGRUEA S. \& S. SUDDEE 2014. Studies in Asian Nervilia (Nerviliae, Epidendroideae, Orchidaceae) IV: N. umphangensis, a new species from the Thai-Myanmar border. Phytotaxa 166: 139-144. https://doi.org/10.11646/phytotaxa.166.2.5

GALE S.W., LI J., KINOSHITA A. \& T. YUKAWA 2015. Studies in Asian Nervilia (Orchidaceae) V: N. futago, a cryptic new species from southwest Japan confirmed by morphological, cytological and molecular analyses. Systematic Botany 40: 413-425. https://doi.org/10.1600/ 036364415 X688772

GALE S.W., SCHUITEMAN A., WATTHANA S., SANDO T., SOUVANNAKHOUMMANE K., AVERYANOV L. \& S. SUDDEE 2016. Studies in Asian Nervilia (Nervilieae, Epidendroideae, Orchidaceae) VI: N. mekongensis, a new species from Thailand, Cambodia, Laos and Vietnam. Phytotaxa 247: 267-273. http:// dx.doi.org/10.11646/phytotaxa.247.4.4
GOVAERTS R., BERNET P., KRATOCHVIL K., GERLACH G., CARR G., ALRICH P., PRIDGEON A.M., PFAHL J., CAMPACCI M.A., BAPTISTA D.H., TIGGES H., SHAW J., CRIBB P.J., GEORGE A., KREUZ K. \& J.J. WOOD 2021. World Checklist of Orchidaceae. Facilitated by the Royal Botanic Gardens, Kew. Available at: http:// apps.kew.org/wcsp/ (Accessed on 11.02.2021).

HOOKER J. D. 1898. Orchidaceae. In: TRIMEN H. (ed.), Handbook to the Flora of Ceylon. Bishen Singh and Mahendra Pal Singh. pp. 132-237.

HSU T.C., CHUNG S.W. \& C.M. KUO 2012. Supplements to the orchid flora of Taiwan (VI). Taiwania 57: 271-277.

JALAL J.S., KUMAR P. \& G.S. RAWAT 2012. Nervilia pangteyana: a new terrestrial orchid from western Himalaya, India. Nordic Journal of Botany 30: 407-411. https://doi.org/10.1111/j.1756-1051.2011.01328.x

JAYAWEERA D.M.A. 1981. Orchidaceae. In: DASSANAYAKE M.D. (ed.), A revised handbook to the flora of ceylon. Volume II. Oxford and IBH, New Delhi. pp. 4-386.

LIN T.P. \& Y.N. CHANG 2013. Newly discovered native orchids of Taiwan (VI). Taiwania 58(4): 257-267. https:/ /doi.org/10.6165/tai.2013.58.257

LIN T.P. 2014. Newly discovered native orchids of Taiwan (VII). Taiwania 59: 360-367. https://doi.org/ 10.6165/ tai.2014.59.4.360

PRIDGEON A.M., CRIBB P.J., CHASE M.W. \& F.N. RASMUSSEN 2005. Genera Orchidacearum. Volume 4. Epidendroideae, Part 1. Oxford University Press, Oxford.

SCHLECHTER R. 1911. Die Polychondreae (Neottiinae Pfitz.) und ihre systematische Einteilung. Botanische Jahrbücher für Systematik, Pflanzengeschichte und Pflanzengeographie 45: 375-410.

SEIDENFADEN G. 1978. Orchid genera in Thailand VI. Neottioideae. Dansk Botanisk Arkiv 32(2): 1-195.

SEIDENFADEN G. \& J.J. WOOD 1992. The Orchids of Peninsular Malaysia and Singapore. Olsen \& Olsen, Fredensborg.

THWAITES G.H.K. 1864. Enumeratio Plantarum Zeylaniae. Dulau \& Co., London, p. 483. 